\title{
The Mechanism of Sand Production Caused by Pore Pressure Fluctuations
}

\author{
M.N.J. Al-Awad ${ }^{1}$ \\ 1 Petroleum Engineering Department, College of Engineering, King Saud University, PO Box 800, Riyadh 11421 - Saudi Arabia \\ e-mail: malawwad@ksu.edu.sa
}

Résumé - Le mécanisme de production de sable provoqué par des fluctuations de la pression de pore - Des échantillons sableux, issus d'une couche de surface d'un réservoir saoudien, ont été testés sous des conditions similaires à celles existant dans le réservoir afin d'étudier l'accroissement de la production de sable avec la fluctuation de pression. L'état de contrainte en fond de puits a été simulé en laboratoire à l'aide d'une presse équipée d'une cellule haute pression Hoek, avec contrôle de la pression de confinement, de la pression de pore et du système d'injection. On a pu ainsi mesurer l'écoulement du fluide dans les conditions in situ.

Dans cette étude, une eau salée à $3 \%$ et du pétrole léger de faible viscosité $(1,5 \mathrm{cP})$ ont été utilisés comme fluides de remplissage et fluides de déplacement. Le fluide déplacé et le sable ont été collectés à la sortie de la cellule de Hoek (diamètre $=4,25 \mathrm{~mm}$ ).

On obtient que la production de sable augmente lorsque le processus de production est stoppé pendant $24 \mathrm{~h}$ puis redémarré ; elle augmente avec la répétition de l'ensemble de ce processus. Par ailleurs, la quantité de sable produite diminue lorsque la pression de fluide se rapproche de la pression initiale : ce déclin est attribué à la hausse de la pression effective de confinement, qui a tendance à contenir les grains sableux et à contrebalancer ainsi les dommages causés au ciment. Les essais de compression indiquent que la résistance du grès est réduite de 8 à $15 \%$ par la succession de trois cycles de production utilisant eau salée et huile légère. Cette réduction de la résistance de la roche est due aux fluctuations de la pression de pore pendant le processus de production de sable.

Mots-clés : production de sable, sable, critère de rupture de Mohr-Coulomb, pression effective de confinement, angle de frottement interne, contrainte, pétrole léger, eau salée.

\footnotetext{
Abstract - The Mechanism of Sand Production Caused by Pore Pressure Fluctuations - Sandstone core samples cored from an outcrop layer of a Saudi sand producer reservoir were tested under simulated bottomhole stress-fluid flow conditions to investigate the process of increased sand production after well shut-in or work-over jobs (i.e. pore fluid pressure fluctuation). Bottomhole stress-state was simulated by using an experimental set-up consisting of a stiff compression machine equipped with a high-pressure Hoek cell, a servo-controlled confining pressure system and a pore pressure and flow generation system. This set-up enables the measurement of fluid flow and sand movement under simulated in situ stresses.

In this work, 3\% saline water and $1.5 \mathrm{cP}$ light oil were used as pore filling fluids as well as displacement fluids. Displaced fluid and sand were produced through the outlet port of the Hoek cell (diameter $=4.25 \mathrm{~mm}$ ). It has been found that an increased amount of sand was produced when the production process was restarted after a shut-in period of $24 \mathrm{~h}$. Higher amounts of sand were produced when successive shut-in processes were performed. Furthermore, the amounts of produced sand
} 


\begin{abstract}
decreased when the pore fluid pressure was brought to its initial value (i.e. immediately before the next shut-in). This decline is attributed to the increase of the effective confining pressure which tends to hold sand grains together as a replacement for the damaged cementing material. As indicated by the compressive tests, about $8 \%$ to $15 \%$ reduction in the strength of the tested sandstone was recorded after the conduction of three successive cycles of production using light oil and saline water. This reduction in rock strength was caused by the fluctuation in the pore fluid pressure during sand production process. Keywords: sand production, sandstone, Mohr-Coulomb failure criteria, effective confining stress, angle of internal friction, confining pressure, light oil, saline water.
\end{abstract}

\section{IN TRO DUCTIO N}

Sand production is considered as one of the major problems in the petroleum industry. Every year, well cleaning and work-over operations, related to sand production and restricted production rates, cost the industry millions of dollars. Additional expenses associated with sand production include pump maintenance, well cleaning, disposal of dirty sands, etc. Sand production occurs when the induced in situ stresses exceed the formation in situ strength [1]. The formation strength is derived mainly from the natural bond caused by the existing cementing materials, that adheres grains together. According to this strength, the sandstone formations can be classified as competent, weak or unconsolidated. In competent sandstone formations, sand production is due to shear failure, which occurs on the surface of the rock (i.e. borehole surface) due to high shear stress. During production, the induced shear failure surfaces are mobilized and sand debris is produced due to the drag forces caused by the reservoir fluid flow. The produced debris (sand) will then flow into the well along with the reservoir fluids [1, 2]. In weak and unconsolidated sandstone formations, sand is produced when the drag forces caused by the flowing reservoir fluids exceed the natural inherent cohesion of the formation. The movement of sand grains leads to the development of sand arches [1-7]. In general, sand production can be classified into three categories [8]:

- transient sand production is normally encountered during clean-up after perforating or acidizing and after water breakthrough in oil secondary recovery operations. At this stage, sand production declines with time at constant production rate;

- continuous sand production is observed during production from unconsolidated sandstone reservoirs that have no sand control equipment;

- catastrophic sand production is the worst case and normally occurs when the reservoir fluids are excessively produced.

Sand production from oil and gas reservoir formations can be minimized using several control methods. The choice of the best applicable method depends on several factors. Among these factors is the formation type. These methods are classified as follows:
- production rate control: several researchers have shown that controlling the oil production rate can minimize sand production [1-4]. This technique is based on the fact that high production leads to a low bottomhole flowing pressure. This reduction in the bottomhole flowing pressure causes the stresses induced in the productive formation to exceed the formation in situ strength. Therefore, localized shear failures will occur in the case of consolidated sandstone and sand arch failure in the case of unconsolidated sandstones and the result will be sand production;

- downhole emulsification: this method involves the injection of an aqueous non-ionic surfactant solution into the wellbore to convert the water-oil emulsion to oil-water emulsion to decrease the carrying capacity of the fluid and at the same time retain sands within the oil phase [9];

- downhole sand consolidation: in this method, chemical solutions such as resins are injected downhole into the productive formation. When it reaches the productive formation, the injected solution will solidify and adhere sand grains together. As an alternative technique, hot air is injected downhole to oxide (cook) the oil phase and provide a cementing material [10-13];

- mechanical sand control: when the proceeding methods fail to control sand production, the mechanical methods are the only solution. They include: the installation of gravel packs, screen liners, or gravel pre-packed screen liners [14].

All the above techniques have been extensively investigated by many researchers [1-29]. An increase in the sand production rate is observed when a well is shut in several times for build-up testing or work-over jobs. The mechanism causing this increase in sand production needs to be investigated. Therefore, the present work was motivated by the investigation of the effect of reservoir pore fluid pressure fluctuation in sand production mechanism.

\section{EXPERIMENTAL SET-UP AN D TESTIN G MATERIALS}

\subsection{Analysis of the Tested Sandstone}

The granulometric analysis of a sandstone sample from an outcrop of a sand producer Saudi oil reservoir was examined using calibrated ASTM (American Society of Testing and Materials) sieves stacked in series. After crushing the 
sandstone sample, a split of $650 \mathrm{~g}$ has been poured onto the top sieve. The set of sieves has been placed in a shaker and shaken for $15 \mathrm{~min}$. After that, the sieves were unloaded and brushed thoroughly. The weight of sand retained in each sieve has been weighed and the percentage values have been calculated (Fig. 1). The grain sizes of the tested sandstone ranged between 20 mesh size $(850 \mu \mathrm{m})$ and 200 mesh size $(75 \mu \mathrm{m})$.

\subsection{Mechanical Properties of the Tested Sandstone}

To avoid any failure of the sandstone samples during fluid flow tests under simulated downhole stresses, the uniaxial compressive strength and the Mohr-Coulomb failure criterion were evaluated as shown in Figure 2. The tested sandstone is homogeneous, reddish in color and moderately weak as indicated by its uniaxial compressive strength (24.5 MPa) and its apparent cohesive strength (7.4 MPa). The pore fluid pressure increase is incorporated into MohrCoulomb failure criteria through the following effective pore fluid pressure law:

$$
\sigma_{\text {eff }}=\sigma_{\text {tot }}-P_{p}
$$

with:

$\sigma_{\text {eff }} \quad$ effective stress

$\sigma_{\text {tot }}$ total stress

$P_{p} \quad$ pore fluid pressure.

An axial stress of $45 \mathrm{MPa}$, a confining pressure of $15 \mathrm{MPa}$ and an initial pore fluid pressure of $2.0 \mathrm{MPa}$ were chosen as they produce a Mohr circle which lies below the failure envelope indicating that no serious shear failure will occur when the sample is initially loaded during the stress-fluid flow tests.

\subsection{Displacing and Displaced Fluids}

The quantity of produced sand from petroleum reservoirs depends on the magnitude of the drag forces created by the displacing fluid and which increase as the flow rate or the fluid viscosity increases. Thus, saline water and light crude oil $(1.5 \mathrm{cP})$ are used as a pore and displacing fluid in this study. The saline water was formulated by dissolving $3.5 \%$ by weight sodium chloride $(\mathrm{NaCl})$ in distilled water.

\subsection{The Experimental Set-up}

An experimental set-up was used to simulate sand production process in oil wells under stress-fluid flow conditions. This rig consists of a stiff compression machine, a Hoek cell, a pore pressure generation and fluid displacement pump and a servo-controlled confining pressure system. The compression machine is used to apply the axial loading while the radial confining pressure is generated using the servo-controlled pressure system. Pore pressure and fluid deriving forces are generated using a constant rate pump as shown in Figure 3.

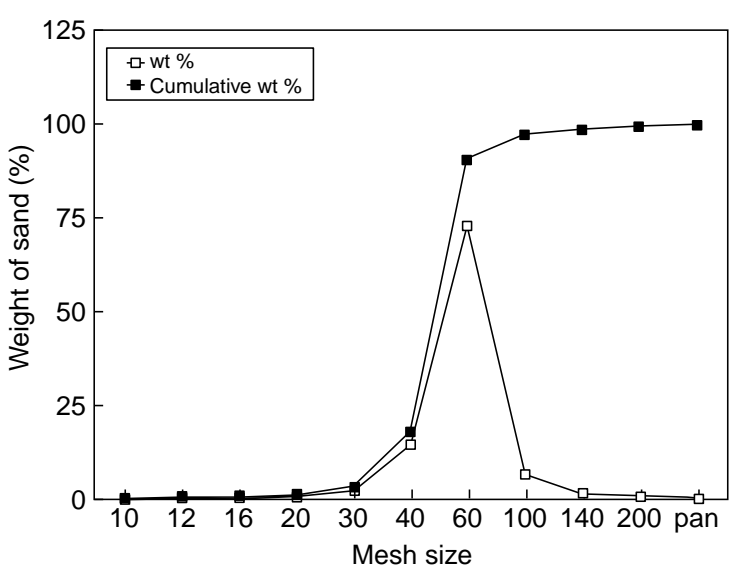

Figure 1

Granulometric analysis of the tested sandstone.

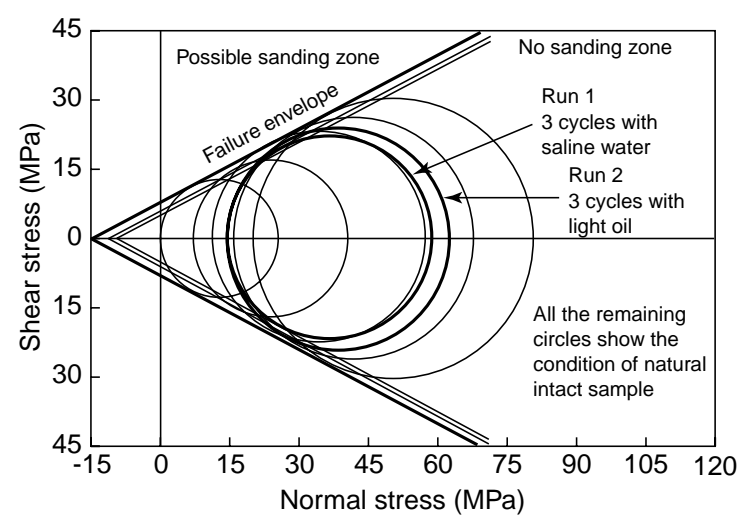

Figure 2

Mohr-Coulomb failure criteria for the tested sandstone at its natural intact, after Run 1, after Run 2.

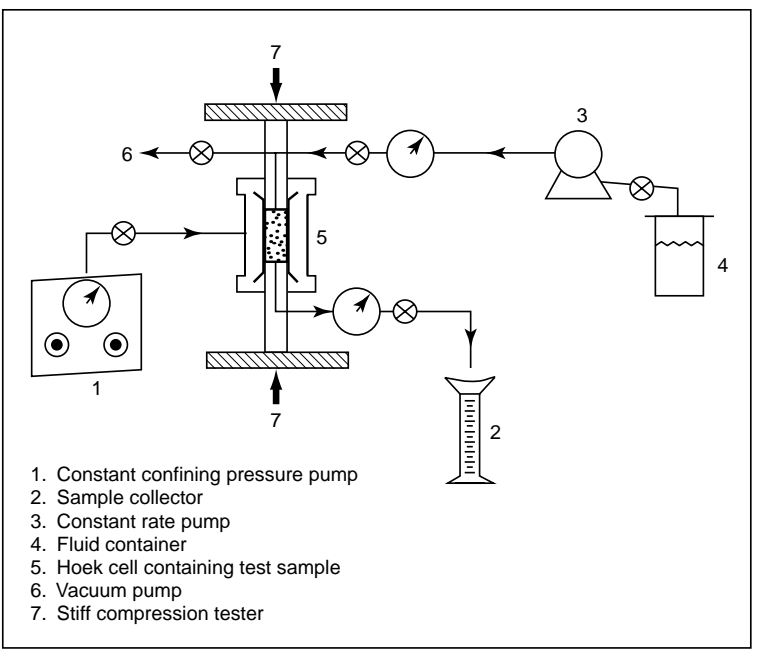

Figure 3

A schematic diagram of stress-fluid flow experimental set-up. 


\section{EXPERIMENTAL PRO CEDURE}

In this work sandstone samples were cored from a bulk sample from an outcrop of a Saudi oil reservoir suffering from sand production problems. The cored samples were prepared according to the specifications of rock mechanical testing outlined by the Society of Rock Mechanics [30]. Granulometric analysis, uniaxial compressive strength and failure criteria were established for this rock (Figs. 1 and 2). Before loading into the experimental stress-fluid flow set-up, samples were saturated with either the light oil of $1.5 \mathrm{cP}$ viscosity or the $3.5 \%$ saline water under vacuum. The following procedures were followed in this work (Fig. 4):

- after full saturation, the sample is mounted into a Hoek triaxial cell, the upper and lower platens are set in place and the confining pressure system is connected to the triaxial cell. An initial confining pressure was applied to fix the rock sample and platens firmly in place and the overall arrangement was placed in the stiff compression machine;

- the fluid inlet line was connected to the arrangement and the displacement pump was switched on to generate an initial pore pressure value;

- the confining pressure, pore fluid pressure and axial load were increased simultaneously until targeted values were reached;

- the set-up was allowed to equilibrate for $3 \mathrm{~h}$ before testing;

- after equilibrium, pore fluid was produced at a constant pressure of $2.0 \mathrm{MPa}$ (at constant axial load and confining pressure) until no more sand was coming out. A second production step was generated by the reduction of the pore pressure to $1.25 \mathrm{MPa}$ and sand was collected again. When no more sand was coming out, the pore pressure was reduced to the final targeted value of $0.50 \mathrm{MPa}$;

- after the end of the third production step, the pore pressure was increased gradually to its initial value (2.0 MPa) and

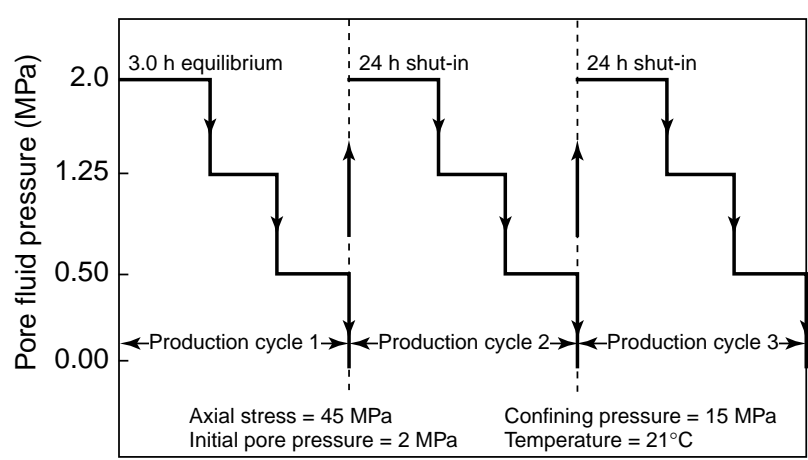

Figure 4

A schematic diagram showing loading conditions and shut-in and production periods.

the set-up was left to equilibrate for $24 \mathrm{~h}$ (shut-in) before the second production cycle (which consists of three production steps as mentioned above) was started;

- a third production cycle was generated after a second $24 \mathrm{~h}$ shut-in by following exactly the same procedure as in the first production cycle outlined above;

- after the third production cycle, the axial stress was increased (at $15 \mathrm{MPa}$ confining pressure with a pore pressure equal to the atmospheric pressure in a drained test) until a shear failure of the test sample was recorded. This was done for the saline water and for the light oil experiments as shown in Table 1.

Figures 5 and 6 show the relationship between the sand/fluid ratio and the applied pore fluid pressure, while Figures 7 and 8 show the relationship between the cumulative sand/fluid ratio and the applied pore fluid pressure using $3.5 \%$ saline water and $1.5 \mathrm{cP}$ light oil.

TABLE 1

Mechanical properties of the tested sandstone before and after sand production process

\begin{tabular}{c|l|c|c|c|c|c|c}
\hline Case & Rock conditions & $\begin{array}{c}\text { Confining } \\
\text { pressure } \\
\text { (MPa) }\end{array}$ & $\begin{array}{c}\text { Axial stress } \\
\text { at failure } \\
\text { (MPa) }\end{array}$ & $\begin{array}{c}\text { Cohesive } \\
\text { strength } \\
(\mathrm{MPa})\end{array}$ & $\begin{array}{c}\text { Internal } \\
\text { friction } \\
\text { angle }\left(^{\circ}\right)\end{array}$ & $\begin{array}{c}\text { Calculated } \\
\text { uniaxial } \\
\text { compressive } \\
\text { strength (MPa) }\end{array}$ & $\begin{array}{c}\text { Reduction } \\
\text { in the uniaxial } \\
\text { compressive } \\
\text { strength }(\%)\end{array}$ \\
\hline Run 1 & $\begin{array}{l}\text { Natural intact } \\
\text { sandstone }\end{array}$ & $\begin{array}{c}\text { Variable } \\
\text { as shown } \\
\text { in Figure 2 }\end{array}$ & $\begin{array}{c}\text { Variable } \\
\text { as shown } \\
\text { in Figure } 2\end{array}$ & 7.40 & 28 & 24.50 & - \\
\hline $\begin{array}{l}\text { After three } \\
\text { production cycles } \\
\text { using light oil }\end{array}$ & 15 & 63.2 & $6.75^{*}$ & 28 & 22.47 & 8.30 \\
\hline $\begin{array}{l}\text { After three } \\
\text { production cycles } \\
\text { using saline water }\end{array}$ & 15 & 59.6 & $6.25^{*}$ & 28 & 20.50 & 15.10 \\
\hline
\end{tabular}

* Estimated assuming constant angle of internal friction for the tested sandstone. 


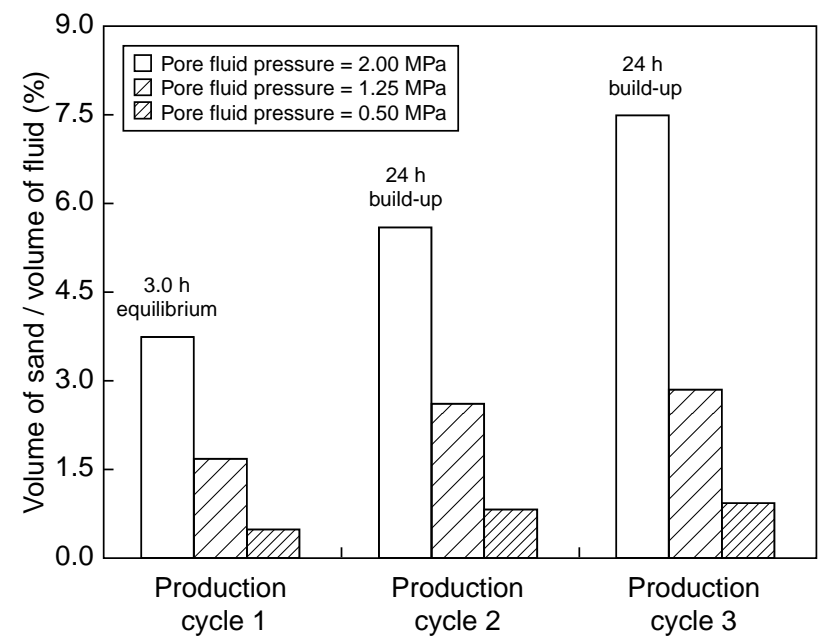

Figure 5

Effect of pore pressure change and build-up period on sand production from a sandstone saturated with $3.5 \%$ saline water.

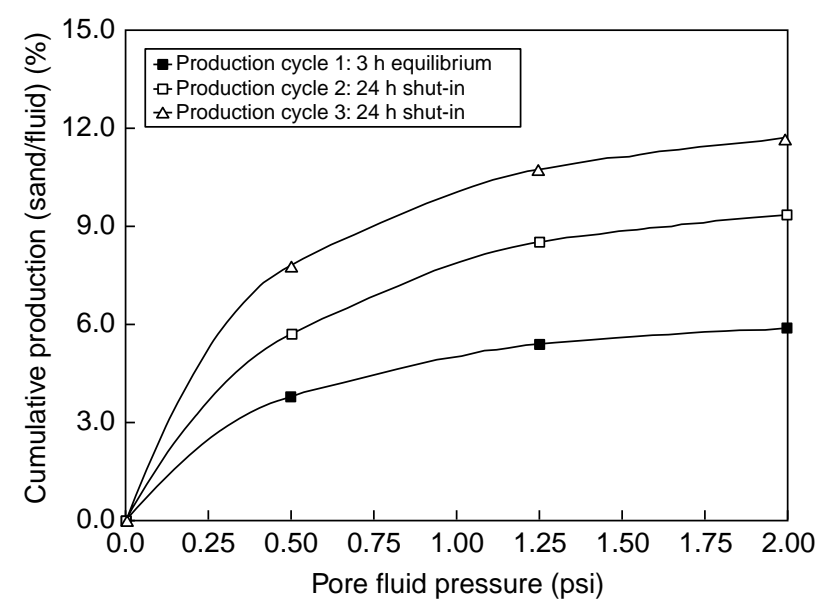

Figure 7

Effect of pore pressure change and shut-in on sand production from a sandstone saturated with $3.5 \%$ saline water.

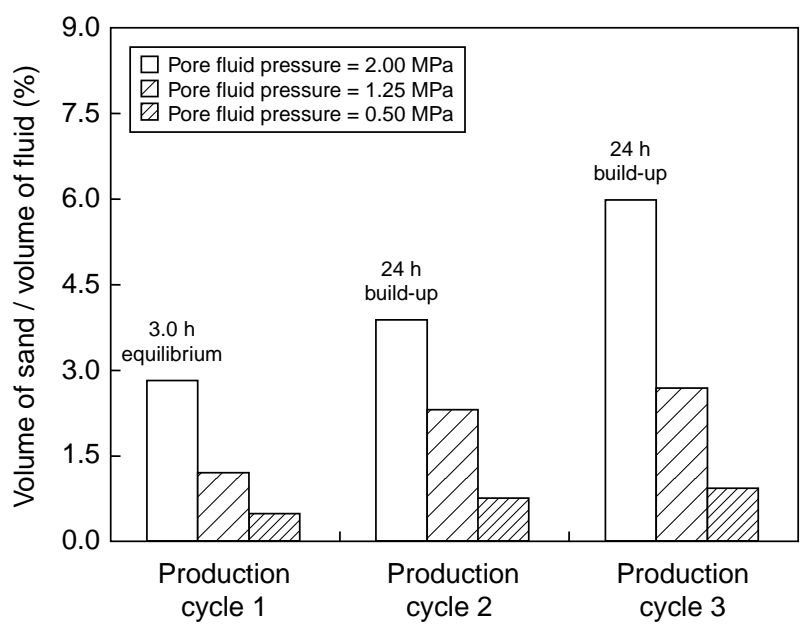

Figure 6

Effect of pore pressure change and build-up period on sand production from a sandstone saturated with $1.5 \mathrm{cP}$ oil.

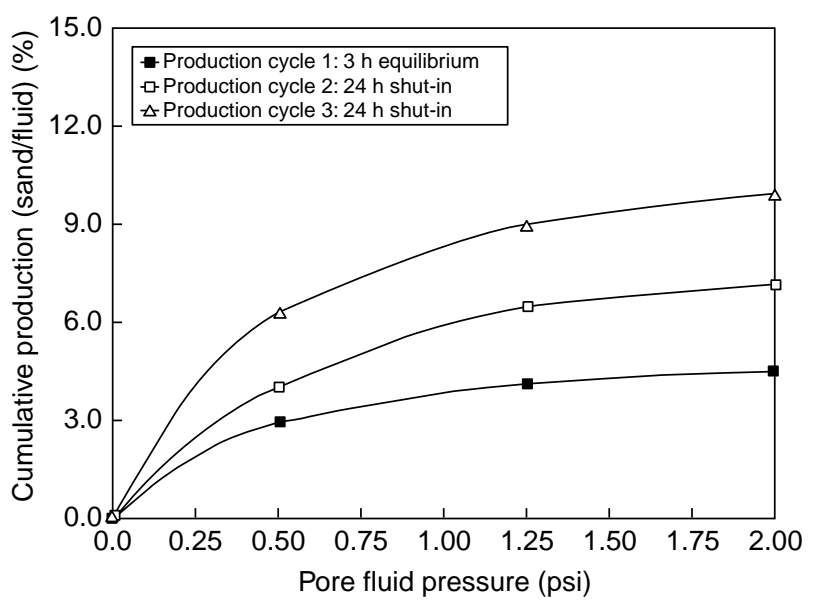

Figure 8

Effect of pore pressure change and shut-in on sand production from a sandstone saturated with $1.5 \mathrm{cP}$ oil.

\section{RESULTS AND DISCUSSION}

The granulometric analysis of the tested sandstone shows that this rock is composed of very fine sand grains as shown in Figure 1. These fine grains can be easily produced when high drag forces exist or a low effective confining pressure (i.e. an increase in the pore fluid pressure) is applied. This sandstone rock can be considered as a moderately weak rock as indicated by the measured uniaxial compressive strength (24.5 MPa) and the estimated apparent cohesive strength (7.4 MPa) as shown in Figure 3. The Mohr-Coulomb failure criteria for the tested sandstone is used to select a loading stress-fluid pressure condition which generates no shear failure as shown in Figure 4. The ratios of the volume of produced sand to the volume of produced fluid at the first production cycle when using $3.5 \%$ saline water were $3.8 \%$, $1.7 \%, 0.50 \%$ at pore fluid pressure of $2.0,1.25$ and $0.5 \mathrm{MPa}$ respectively. It is clear that, at high pore fluid pressure, higher amounts of sand are produced due to the decrease in the effective confining pressure and vice versa. The amount of produced sand decreased as the pore pressure decreased due to the increase in the effective confining pressure holding sand grains together. It should be noticed that when the pore pressure was raised to its initial value after $24 \mathrm{~h}$ build-up, more sand was produced because higher amounts of sand were available to move with the displacing fluid when 
compared to the first production cycle $(5.7 \%, 2.7 \%$ and $0.8 \%$ at the same pore pressure values as applied in the first production cycle). This free sand was generated by the damage of the cementing material caused by the increase in the effective confining pressure caused by the reduction in the pore fluid pressure in the first production cycle. Further, an increase in the amount of produced sand was noticed in the third cycle for the reason mentioned above $(7.9 \%, 3.0 \%$ and $1.0 \%$ at the same pore pressure values as applied in the first and the second production cycles).

If compared to the saline water, lower amounts of sand were produced when light oil was used as a displacing fluid (Fig. 6). This is due to the effect of water on the cementing material holding sand grains to each other. The general sand production in the case of light oil follows exactly the trend of the saline water case (Figs. 7 and 8) indicating the bad effect of pressure build-up (fluctuation) on the mechanical properties of the reservoir rock.

As sand is produced due to pore pressure fluctuation, test samples suffer strength reduction as indicated by the triaxial (confined) compressive strength measured at the natural state of the samples and at the end of each experiment. It was found (as shown in Table 1) that in the case of saline water, the test sample has lost about $15 \%$ of its strength due to the sand production caused by the pore pressure fluctuations while in the case of light oil the test sample has lost about $8.3 \%$ of its initial strength.

\section{CONCLUSIONS}

Based on the analysis performed in this work, the following conclusions are obtained:

- when a shut-in process is performed, the pore fluid pressure reaches its initial (maximum) value causing a decrease in the effective confining stress;

- at low pore fluid pressure, the effective stress increases causing a damage to the cementing material bonding sand grains together;

- due to drag forces and a low effective confining pressure, sand starts to produce in large amounts at high pore pressure immediately after the termination of the build-up process;

- a clear decrease in the amount of produced sand is noticed due to the increase in the effective overburden stress which holds sand grains firmly together;

- repeated fluctuations in the pore fluid pressure can seriously damage the cementing material bonding sand grains together, leading to higher amounts of produced sand;

- saline water seriously damages the sandstone cementing material, leading to higher amounts of free sand ready to move to the wellbore if compared to the light oil situation;

- sand production due to pore pressure fluctuation leads to a noticeable reduction in the productive formation.

\section{REFEREN CES}

1 Al-Awad, M.N.J. and Desouky, S.E.M. (1997) Prediction of Sand Production from a Saudi Sandstone Reservoir. Oil \& Gas Science and Technology, 52, 4, 1-8.

2 Al-Awad, M.N.J. (1997) The Investigation of the Source of Sand Produced from Competent Sandstone Reservoirs. Second Jordanian Conference on Mining, Amman, April 2629, 393-405.

3 Al-Awad, M.N.J. and Al-Misned, O.A. (1997) Rock Failure Criteria: A Key for Predicting Sand-Free Production Rates. Journal of the Egyptian Society of Engineers, 36, 2, 53-58.

4 Al-Awad, M.N.J., El-Sayed, A.A.H. and Desouky, S.E.M. (1999) Factors Affecting Sand Production from Unconsolidated Sandstone Saudi Oil and Gas Reservoir. Journal of King Saud University, Engineering Sciences, 11, $1,151-174$.

5 Oshita, T., Aziz, A. and Rammah, Y. (1997) Integrated Approach for Sand Management: Field Application to an Offshore Oil Field. Middle East Oil Show, Bahrain, March 15-18, SPE 37767, 537-546.

6 Desai, S. (1988) Sand Production Model for Safaniya Field, Saudi Arabia. Thesis, Louisiana Technical University, Ruston, Louisiana.

7 Tronvoll, J., Morita, N. and Santarelli, F.J. (1992) Perforation Cavity Stability: Comprehensive Laboratory Experiments and Numerical Analysis. 67th Annual Technical Conference \& Exhibition, Washington DC, October 4-7, SPE 24799.

8 Veeken, C.A.M., Dacies, C.J., Kenter, C.J. and Kooijman, A.P. (1991) Sand Production Prediction Review: Developing an Integrated Approach. 66th Annual Technical Conference \& Exhibition, Dallas, Texas, October 6-9, SPE 22792, 335346.

9 Al-Awad, M.N.J. (1997) Controlling Sand Production in Heavy Oil Formations Using Downhole Emulsification Process. Indian Journal of Engineering, 7, 3, 171-179.

10 Gunnigham, M., Nwogbe, P.C., Kool, H. and Freeman, A. (1996) Selective Sand Consolidation Technique Using a Pin-Point Injection Packer. SPE European Petroleum Conference, Milan, October 22-24, SPE 36888.

11 Fitzgrald, B.M., Clynn, S. and Terwilliger, P.L. (1966) Warm Air Cooking Sand Consolidation-Field Results in Viscous Oil Sands. Journal of Petroleum Technology, USA, January, 35-42.

12 Spurlock, J.W., Howard, G.C., Bearden, W.G. and Blenkarn, K.A. (1966) A Deformable Material for Sand Consolidation. Journal of Petroleum Technology, USA, March, 306-312.

13 Aggour, M.A., El-Sayed, A.O. and Abu-Khamsin, S. (1996) In Situ Sand Consolidation by Low-Temperature Oxidation. SPE Annual Technical Conference, Denver, Colorado, October 6-9, SPE 36626.

14 Ciriglino, J.A. and Leibach, R.E. (1967) Gravel Packing in Venezuela. 7th World Congress, Mexico City, Mexico, April 2-8.

15 Ramos, G.G., Katahara, K.W., Gary, J.D. and Knox, D.J.W. (1994) Sand Production in Vertical and Horizontal Wells in a Friable Sandstone Formation, North Sea. Proc. of Eurock '94: Rock Mechanics for Petroleum Engineering, Delft, The Netherlands, August 29-31.

16 Sarda, J.P., Kessler, N., Wicqart, E., Hannaford, K. and Deflandre, J.P. (1993) Use of Porosity as a Strength Indicator for Sand Production Evaluation. 68th SPE Annual Technical Conference \& Exhibition, Houston, Texas, October 3-6, SPE 26454. 
17 Tronvoll, J. (1992) Experimental Investigation of Perforation Cavity Stability, in Rock Mechanics, Balkema, Rotterdam, 365-373.

18 Tronvoll, J., Nobuo, M. and Santralli, F.J. (1992) Perforation Cavity Stability: Comprehensive Laboratory Experiments and Numerical Analysis. 67th Annual Technical Conference, Washington DC, October 4-7, SPE 24799.

19 Somerville, J.M., Smart, B.G.D. and Farquhar, R.A. (1994) The Potential for Sand Production: Assessment by Finite Element Modelling. 69th SPE Annual Technical Conference \& Exhibition, New Orleans, Louisiana, September 25-28, SPE 28557, 439-448.

20 Nobuo, M. (1994) Field and Laboratory Verification of SandProduction Prediction Models. SPE Drilling \& Completion, December, 227-235.

21 Cook, J.M., Bradford, I.D.R. and Plumb, R.A. (1994) A Study of the Physical Mechanisms of Sanding and Application to Sand Production Prediction. European Petroleum Conference, London, October, 25-27, SPE 18852.

22 Van den Hoek, P.J., Hrtogh, G.M.M., Kooijman, A.P., Bree, D. and Kenter, C.J. (1996) A New Concept of Sand Production Prediction: Theory and Laboratory Experiments. SPE Annual Technical Conference \& Exhibition, Denver, Colorado, October 6-9, SPE 36418, 19-33.

23 Kooijman, A.P., Van den Hoek, P.J., Hrtogh, G.M.M., Bree, D. and Kenter, C.J. (1996) Horizontal Wellbore Stability and Sand Production in Weakly Consolidated Sandstones. SPE Annual Technical Conference \& Exhibition, Denver, Colorado, October 6-9, SPE 36418, 35-48.
24 Fjaer, E., Holt, R.M., Horsrud, P., Raaen, A.R. and Risnes, R. (1992) Petroleum Related Rock Mechanics, 1st edition, Elsevier Science Publishers B.V., Amsterdam.

25 Sanfilippo, F., Ripa, M. and Santarelli, F.J. (1995) Economical Management of Sand Production by a Methodology Validated on an Extensive Database of Field Data. SPE Annual Technical Conference \& Exhibition, Dallas, Texas, October 22-25, SPE 30472.

26 Tronvoll, J. and Fjaer, E. (1994) Experimental Study of Sand Production from Perforation Cavities. International Journal of Rock Mechanics and Mining Sciences \& Geomechanical Abstracts, 31, 5, 393-410.

27 Stein, N., Odeh, A.S. and Jones, L.G. (1974) Estimating Maximum Sand-Free Production Rates from Friable Sands for Different Well Completion Geometries. Journal of Petroleum Technology, October, 1156-1158.

28 Morita, N. (1994) Field and Laboratory Verification of Sand Production Prediction Methods. International Symposium on Formation Damage Control Procedures, Lafayette, California, February 7-10, SPE 27341.

29 Morita, N., Whitfill, D.L., Massie, I. and Knudsen, T.W. (1987) Realistic Sand Production Prediction: Numerical Approach. 62nd SPE Annual Technical Conference \& Exhibition, Dallas, Texas, September 27-30, SPE 16989.

30 Kavori, K., Tisa, A., Einstien, H.H. and Frankline, J.A. (1983) Suggested Methods for Determining the Strength of Rock Materials in Triaxial Compression (revised version). International Society of Rock Mechanics Abstracts, 20, 6.

Final manuscript received in February 2001 